\title{
Is Psalm 104 an expression (also) of dark green religion?
}

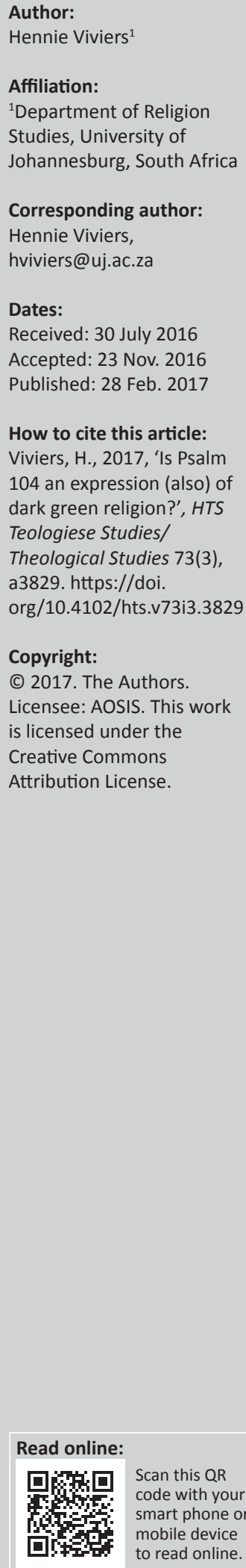

Bron Taylor defines dark green religion as follows: '... a deep sense of belonging to and connectedness in nature, while perceiving the earth and its living systems to be sacred and interconnected'. Can Psalm 104, with its conspicuous focus on nature, also be described as an expression of dark green religion? Utilising especially the dark green values of belonging, interconnectedness and sacredness, it was found that the psalm aptly confirms Earth as home, illustrates a deep-seated kinship with other living creatures and acknowledges nature as intrinsically worthy or sacred through its close association with God. Of the four kinds of dark green religion, Gaian Naturalism and Naturalistic Animism ('Darwinist', naturalist view), Gaian Spirituality and Spiritual Animism (supernaturalist view), the psalm belongs to the lastmentioned, acknowledging Yahweh as upholding and 'permeating' the harmonious whole of creation. The poet is, however, also well informed of 'natural' knowledge of his environment (for his time obviously). The psalm's joy, awe, astonishment, humility and fear (to a limited extent), being almost overwhelmed by awesome nature, are emotions that can also be shared by adherers to the naturalist view, those who doubt if there is some spiritual world running parallel to the natural world. The religious-like experience of naturalists provides common ground with the religious and enhances a much-needed change of view of respect towards nature.

\section{Introduction}

Psalm 104 is a well-known psalm in the Old Testament. It is especially known for its embracement of nature - its creation, its well-balanced functioning to enhance and sustain life, and a conspicuous harmonious relationship between God, human and the whole of the created order. The psalm is, therefore, seemingly 'green' or eco-friendly, something that applies only to a minority of texts in the Bible with its mostly anthropocentric focus. Texts are rich in meaning and can fulfil quite different functions for their receivers or readers throughout their existence and the same applies to Psalm 104. Apart from all the diverse meaning-given questions put to the psalm, past and present, the question in this article is a decisively 'green' one, moreover, a 'dark green' one. Does Psalm 104 subscribe to dark green values? This hermeneutical lens inquires if and in which ways the psalm embraces nature as intrinsically worthy. The psalm is at first glance also very theocentric and this evokes an accompanying question on the poet's God, is he 'green' also, especially when compared to images of God elsewhere in the Bible?

Bron Taylor in his 2010 book, Dark Green Religion: Nature Spirituality and the Planetary Future, analyses a wide array of expressions of dark green sentiments as they become manifested in influential individuals, organisations and artworks like novels, poetry, films and so on. In the same way that he has highlighted some (mostly modern) dark green poems, I focus on Psalm 104 as an ancient Near Eastern poem to determine if it has a similar penetrating focus on nature and if the last-mentioned is indeed valued. Furthermore, dark green religion, even though called 'religion', does not necessarily need a 'god' to cherish nature as sacred. Can the awe or wonder in Psalm 104 be shared by adherents who have a naturalist instead of a supernaturalist worldview and who respect 'life' as it is expressed in manifold, wondrous forms in nature? Is there common ground between an ancient psalmist or modern believer and a modern 'Darwinist'?

In what follows, the hermeneutics of dark green religion is explained first. Psalm 104 is then subjected to a dark green analysis to determine if and how it can be described as an expression of dark green religion (also).

\section{Dark green religion}

Bron Taylor (2010:13) defines dark green religion as follows: '... a deep sense of belonging to and connectedness in nature, while perceiving the earth and its living systems to be sacred 
and interconnected'. The ultimate experience of this existential bond ${ }^{1}$ between human and nature, of having a meaningful place in the bigger scheme of things, is what dark green religion or nature spirituality is all about. The respect for nature, even inclining to an attitude of reverence (Taylor 2008:89), binds people across the board, notably those that are religious and those that opt instead for a naturalistic worldview. The description dark green, especially the word dark, has therefore to do with the depth of consideration of nature, similar to deep ecology. It is clear also from these few comments that the boundaries of religion, of what it is and what not, are extended to include convictions and attitudes that would not usually or traditionally be considered 'religious'. Substantive definitions of what religion comprises (gods, spirits, holy places, rituals, holy scriptures, etc.) are commonly too narrow to include everything that could fall under the rubric of religion. Functionalist definitions, what religion does to people in regard to its anchoring and elevating capacities, are often too wide to include almost everything that smacks of religion (e.g. sports and its uplifting effects for both players and spectators) (Greaves \& Chryssides 2007:26-34; Krüger, Lubbe \& Steyn 2009:3-9). Taylor (2010:2), therefore, prefers to fit dark green religion under the 'family resemblances' ('polyfocal') approach to religion, acknowledging the wide array of beliefs and behaviours all its adherents might have but nevertheless represents a religious-resembling appreciation and treatment of nature. (Nature) spirituality not only has a more comprehensive meaning than just the traditional belief in nonmaterial, supernatural beings but also implies an understanding of '... one's place in the cosmos' (Taylor 2010:3) and an experience of a (naturalistic) metaphysics of connection. 'Dark green religionists' might differ completely in terms of supernatural and naturalistic convictions but share religious-like emotions (e.g. awe and wonderment, oceanic feelings of oneness) and questions of meaning (why is there a universe and life [and death], what is one's place here, what would an ethics of care towards nature look like?). ${ }^{2}$ It is especially religious-like jargon $^{3}$ that is shared by diverse individuals and groups expressing their ultimate experiences of nature. These deep experiences of (notably 'wild') nature are conspicuously sensuous and translate into an awareness of its sacredness (Taylor 2010:45-47). Therefore, the well-known producer of nature documentaries, (agnostic) David Attenborough, can express his 'ecstatic's delight and wonderment in nature similarly to that of the ancient, theistic poet of Psalm 104 (v. 24 'How wonderful your works O God ...').

\footnotetext{
1.This almost religious-like bond is aptly reflected by the etymology of the word 'religion', '... from the Latin re (again) and ligare (to connect) ...' (Taylor 2010:2).

2.Taylor (2010:14) indicates that likewise as some shared countercultural ideas bind different people together in an alternative 'cultic milieu', so the same kind of shared 'green' (nature embracing) sentiments unite diverse people in the nonmainstream 'environmental milieu'.

3.The cell biologist Ursula Goodenough (2005:1372) is a telling example. Despite being non-theistic, she nevertheless uses religious-emotional terminology of awe and wonderment to capture the 'miracle' of the mechanisms of biochemistry. This echoes (agnostic) Charles Darwin (1859:490) who similarly spoke of the '... grandeur of this view of life [evolution - HV] ...'. Many nonbelieving scientists serve themselves with religious language analogical to the use of 'anthropomorphic' language, when for instance describing animal behaviour (Taylor 2010:40).

4.Attenborough is described as a 'missionary' of 'ecstatic naturalism' of a nonsupernaturalistic, pantheistic kind (Taylor 2010:146).
}

When Taylor (2013) expands on dark green religion's value system as:

... (1) based on a felt kinship with the rest of life, often derived from a Darwinian understanding that all forms of life have evolved from a common ancestor and are therefore related; (2) accompanied by feelings of humility and a corresponding critique of moral superiority, often inspired or reinforced by a science-based cosmology that reveals how tiny human beings are in the universe; and (3) reinforced by metaphysics of interconnection and the idea of interdependence (mutual influence and reciprocal dependence) found in the sciences, especially in ecology and physics ... (p. 13)

it cannot but lead to an internalised ethics of care (Taylor 2010:41) towards nature as really worthy of caring for and living in harmony with. From the Earth Bible approach, Habel (2009:43-46) independently echoes these same values of kinship, interconnectedness and interdependence with other life forms and insists that humans should '... respect their rights'. Humans are but one miniscule speck in the universe. The last-mentioned was not made for them and neither does the diversity of species serve only their needs; each animal '... was made for itself' (John Muir cited in Taylor 2010:68). ${ }^{5}$ If humans destroy the world, they destroy themselves, something that was intuitively grasped by spiritually perceptive indigenous cultures, quite the opposite to Western thought. Jean-Jacques Rousseau believed because they lived closer to nature they had a natural sympathy and compassion for nature and believed in an 'expansive self' that includes nature. The lastmentioned was also emphasised by the famous Chief Seattle that everything (rock, dew, flower, eagle, deer, bear, human) belongs to the 'same (earth - HV) family' (Taylor 2010:9, 175). ${ }^{6}$

\section{In order for Taylor (2010) to illustrate that:}

... dark green religious and moral sentiments are embedded in worldviews and narratives that are believed to cohere with science - but they are also (my emphasis - HV) often grounded in mystical or intuitive knowledge that is beyond the reach of scientific method. (pp. 14, 15)

he identifies four types of dark green religion expressions that can be schematically presented as follows:

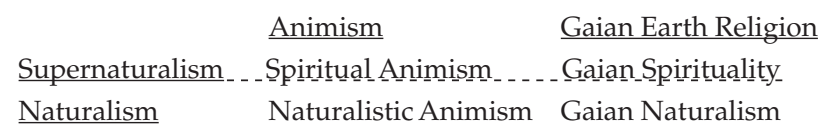

The dashed line between supernaturalism and naturalism indicates that representatives sometimes find themselves in both worlds, appreciating science on the one hand and admitting to a greater reality that can perhaps most

5 So also Attenborough: ... all living things were not made for man, many of them have no relation to him, their happiness and enjoyments, their loves and hates would seem to be immediately related to their own well-being and perpetuation alone (cited in Taylor 2010:143).

6 Taylor (2010:175) captures his famous original words: We know the sap which courses through the trees as we know the blood that courses through our veins. We are part of the earth and it is part of us. The perfumed flowers are our sisters. The bear, the deer, the great eagle, these are our brothers. The rocky crests, the dew in the meadow, the body heat of the pony, and man all belong to the same family. 
meaningfully only be 'known' through mystical experience on the other hand. Spiritual Animism assumes some animating source, usually called 'god/spirit' or 'spiritual intelligences' (Taylor 2010:15), bringing natural elements (e.g. rock, river, tree, animal, human) to life and sustaining them with life, and causing these elements to be venerated because of their sacredness of being touched or incarnated by 'god'. Among indigenous cultures especially it is not difficult to transcend the boundary between the material and the immaterial, the mundane and the sublime, and humans and other living things. In regard to the latter, the theriomorphism or what Taylor (2010:44) aptly refers to as 'shape-shifting' of the San shaman, changing into half human half animal during trance, is well known (Krüger 1995:316-325). The whole of the San's reality is animated, monistic and fluid (Krüger 1995:295-315), emphasising succinctly their grasp of interconnectedness or interdependence or kinship. Habel (2009:45) also illustrates the last-mentioned among the Australian Aborigines who experience a close kinship bond with a bird, animal or some life form with whom they share their daily lives. Naturalistic Animism doubts if there is some supernatural or superordinate 'personalised force' invigorating earthly things but prefers rather to speak of the (natural) life-force ${ }^{7}$ as it became expressed in astounding, diversified manifestations through evolution. Taylor (2010:24-31) exemplifies especially the cognitive ethologist Marc Bekoff and primatologist Jane Goodall, ${ }^{8}$ who have highlighted the conscious and moral lives of canines and chimpanzees, respectively. The mental 'overlap' (interconnectedness) between humans and animals becomes notably clear in meaningful non-verbal communication (eye-to-eye or touch) between them. Taylor (2010:89-90) portrays David Abram's animist perception tellingly in his contact with inter alia a bison when they stumbled into each other during a hiking expedition - '... Our eyes locked. When it stared, I stared back ... when I tossed my head, it tossed its own in reply...'. 9

Gaian Naturalism and Gaian Spirituality: 'Gaia' is the Greek name of the goddess who represented or incarnated the Earth. The whole of the cosmos is regarded as a wellfunctioning, living organism consisting of different living parts, all contributing to its harmonious and balanced existence. The Gaia theory was promoted especially by James Lovelock (Taylor 2010:35-41), a natural scientist, who nevertheless expressed the human need for reaching out to something larger than oneself. This he did by putting his 'trust' (sic - religious term! Taylor 2010:38) in the reliable cosmos that has evolved and sustained life for millions of years. Earth is not 'god' (Lovelock is agnostic) but can be relied on in a similar way as believers depend on their 'god(s)'. Two early North American influential dark green religionists who expressed similar views are Aldo Leopold

7.Dave Foreman, a radical environmentalist and cofounder of the civil disobedient 'Earth First!' movement, speaks of the 'flow of life' or the 'process of life', to substitute the life-force as a nonsupernatural concept of the sacred (Taylor 2010:80).

8.She did, however, retain something of her childhood theism (Taylor 2010:27).

9.From a cognitive point of view, this is probably the result of interacting mirror neurons that humans and non-human animals share and where they imitate each other's actions. and John Muir. Leopold emphasised the earth as a community instead of a commodity, the last-mentioned was the mainstream view of early European settlers on American soil (Taylor 2010:31-32, 44, 68-69). Leopold regarded himself as pantheist and believed in the laws of nature upholding the universe instead of a personal god. Muir in the same vein appreciated the cycles of life keeping everything in the world intact and acknowledging nature as more marvellous and mysterious than the so-called supernatural. Part of the cycle of life is death, to '... reunite with and nurture the Earth' says Taylor (2005:455) when appreciating the poet Robinson Jeffers and novelist Edward Abbey. Jeffers dreams of becoming part of a vulture (its eyes and its wings) when incorporated by it after death out in the open. Abbey visualises becoming part of his beloved desert, dissolving to become desert-coloured nourishment for this sacred landscape. Gaian spirituality holds to the same organicist, holistic view, except for postulating a supernatural 'god' behind the universe. It also serves itself of nonmainstream science to undergird its pantheistic or panentheistic metaphysics, whereas the naturalistic version is informed by mainstream science (e.g. evolutionary theory) (Taylor 2010:16). Both Gaia versions, however, share the awe and astonishment of standing before and being part of this encompassing entirety.

Taylor writes illuminatingly on diverse expressions of dark green religions, through influential figures of the past and present - scientists and non-scientists, writers, poets, artists, film makers - through green movements and NGOs, and through interesting expressions such as surfing spirituality (Taylor 2010:103-126), the marine counterpart of the earthly. He also highlights the negative 'dark' side of dark green religion (pace its positive meaning of intense focus) in some forms of radical environmentalism (Taylor 2010:71-102). Here, it often surfaces through fascistic views, misanthropy and an accompanying general stance of anti-sociality where human needs are almost completely ignored (Taylor 2010:101). At first glance, this rich and widespread diversity might seem confusing, but it is not. That which binds all together is aptly summed up by Taylor (2010:102) as follows: 'The heart of dark green religion is to be found in the belief that everything in the biosphere is interdependent, intrinsically valuable, and sacred'. It is now time to take a closer look at Psalm 104 and determine whether it meets the requirements of being dark green.

\section{The 'dark green' Psalm 104}

When Weiser (1962:666) compares Psalm 104 to Genesis 1 as a '... coloured picture to the clear lines of a woodcut' (or 'impressionistic' - Schaefer 2001:257), he not only appreciates the unique beauty of this individual song of descriptive praise (Westermann 1989:247) but also raises the contestation about its dating. Does it expand on the postexilic (priestly) Genesis 1 or does it precede it from a much earlier date, to inspire it (Allen 1983:31, referring to Van der Voort); or do both rely on common ideas in the Ancient Near East about creation (Davidson 1998:339)? Most interpreters 
have noticed the psalm's strong resemblance with the hymn of the Egyptian pharaoh Akhenaten (Amenophis IV, 13651348 BCE) to the sun-god (disc) Aten as well as reflecting the Canaanite mythic pattern, exemplified by the storm-god Baal (Walker-Jones 2001:88). ${ }^{10}$ But, its difference has also been noted, the Israelite God is the creator and not creation (Kraus 1992:36). The psalm's royal clothing of Yahweh in the apparel of Aten and Baal, ${ }^{11}$ and its possible use as a war liturgy by the king, strongly points to a pre-exilic date (Pretorius 2016; also Dahood 1970:33). Even though these historical questions (also those on structure, intertextuality and so on, usually asked) are important, they lie outside the scope of this article. ${ }^{12}$ My interest in the psalm is a modern readerly one, investigating the psalm for possible (dark) 'green' values to which it might subscribe, and its continuous inspiration for today.

The depiction of the cosmos in Psalm 104 has insightfully been recognised by an early commentator as '... a single allembracing organism based on a divine and meaningful world-order' (Weiser 1962:668). Mays, in the same vein, speaks of an interdependent 'intricate system' (1994:334), and Walker-Jones (2001:94) reiterates the vision of the psalm as that of a large, living organism, matching Lovelock's ideas of the Earth as 'Gaia', a unified and balanced whole where all its interconnected elements (bio- and elemental) contribute to its life. If Psalm 104 reflects the dark green variant of 'Gaian Spirituality' where Yahweh upholds and sustains all that he has created, skilfully structured and harmoniously ordered (through hokmāh, v. 24), the whole of awe-inspiring nature becomes his testimony ('message' - Kraus 1992:37) of trust. God might not be seen directly, but his handiwork in nature can, evoking trust and confidence for all life forms to thrive. Psalm 104 explicitly also reflects 'Spiritual Animism', where Yahweh animates the creaturely with his life-giving breath (rûah, v. 29, 30; 'divine inbreathing' - Briggs \& Briggs 1907:336) so that the heavens (atmosphere), earth and sea teem with life. The notions of belonging, interconnectedness and sacredness (see Taylor's definition above) will further confirm these few preliminary remarks of the psalm's dark green sentiments.

\section{Belonging}

Belonging implies to be 'at home', both physically and also mentally (emotionally or spiritually). The psalm interestingly

10.This mythic pattern comprises first of all a march by the divine warrior and his accompanying (thunderstorm) assembly, followed by a battle with earthly and mythological enemies and finally the establishment of the god's monarchy and rule, evoking fertility from the earth (Walker-Jones 2001:89).

11.Egyptian influence might have been mediated indirectly to (pre-exilic) Israelite scribes via the Phoenicians, who had close commercial and cultural ties with Egypt (Dahood 1970:33 following Georges Nagel; see also Pretorius 2016).

12.A brief comment though on its place in the Psalter as part of the so-called 'Halleluyah' psalms: although most interpreters point out the first appearance of 'Halleluyah' in the Psalter at the end of Psalm 104, they also follow the LXX to move it as a heading to the next psalm. This, however, remains an open question as the heading to the next 'psalu. 'Th', hower, positional pattern of "Hallelu-yah' in Psalm 104 (end), Psalm 105 (end) and Psalm 106 (beginning and end) is repeated similarly in a later group of 'Hallelu-yah' psalms (Ps 115-117) (Palmer Robertson 2015:265-266). The 'Hallelu-yah' group (Ps 104-106) ending Book 4 in a climactic way (see also Ps 146-150 ending Book 5) in the final redaction of the Psalter could add a later layer of inspirational meaning to its readers where Book 4 has a stronger contextual focus on the exile (Zenger \& Hossfeld 2011:39-41). opens with (a kingly) Yahweh preparing himself a home, his 'upper chambers' ('ăliyyôtāyw) in the skies above, with the clouds, winds and lightning as his angelic servants and ministers, the typical residing place of Ancient Near Eastern gods. And how much Yahweh is 'at home' here on earth will become clear later on. The rest of the cosmos is artfully structured and put in place, the solid, unmovable earth, the mountains and the valleys, the primordial waters encircling everything and generating fountains from below and rain from above, all have their designated places and become the life-sustaining habitats for the rich diversity of living creatures. The wild animals (onagers, ibexes, hyraxes) have the mountains and the valleys, the birds 'nest' (škn, v. 12) in the trees beside the streams and similarly the stork that has its 'home' (byt, v. 17) in the cedars and firs of the Lebanon. Even these magnificent trees have their specific habitat in the well-watered Lebanon mountain range. Lions have 'their dens' (méônotām, v. 22), humans have their work and living place (implied) and the vast sea accommodates both animals and humans (temporarily in their ships).

Shelter and food go hand in hand, and even the ancient poet has a fine grasp of the modern ecological term 'habitat' to provide precisely this. The poet has a strong fixation on the life-giving sustenance of water in the first half of the poem, understandable in an arid landscape like ancient Palestine, but also later on an appreciation for the sea which was usually feared (Allen 1983:34). The springs in the mountains and valleys sustain the wild animals and birds; Yahweh 'waters' the mountains and earth (v. 10-13, 16). Trees can grow there and notably vegetation for animals and humans to live from: '... grass grow ${ }^{13}$ for the cattle ... plants for man to cultivate, bringing forth food from the earth' (v. 14), and wine, oil ${ }^{14}$ and bread for human consumption. Lions 'pray' (Allen 1983:33) to God for their food (v. 21; see also Job 38:41). The image of God opening his hand to provide food to all earthlings (v. 27-28) reminds of a farmer feeding his animals or the head of a household providing for all (Kraus 1992:65; Westermann 1989:251). The ancient poet shows a remarkable intuition for the attraction towards water ${ }^{15}$ and 'green'. Apart from the need for water, he also appreciates 'green' as an index of the life-force emanating from Yahweh as his spirit or breath: verse $30^{\prime}$ '... you renew the face of the earth'. Without these, there is no survival and therefore humans have, in their evolutionary history, developed an innate attraction for such life-sustaining environments (Kaplan \& Kaplan 1989:9). The poet in an eco-friendly way extends the need for water and green vegetation notably also to non-human animals as all share and 'belong' to the same cosmos.

13.Walker-jones (2001:95) indicates that the participle mașiat (v. 14), to bring forth vegetation, could also indicate Earth as subject and not only God (see Gn 1:12, 24).

14.'In Semitic idiom, the full or fattened face symbolises glowing health' (Dahood 1970:41).

15.Taylor (2010:150) refers to the Canadian scientist and producer of documentaries David Suzuki who eloquently speaks of water as follows: We are water - the oceans flow through our veins, and our cells are inflated by water, our metabolic reactions mediated in aqueous solution ... As air is sacred gas, so is water a sacred liquid that mediated in aqueous solution ... As air is sacred gas, so is water a sacred liquid that
links us to all the oceans of the world and ties us back in time to the very birthplace links us to
of all life. 
When Mays (1994:331) speaks of Psalm 104 including the '... scientific and economic and aesthetic ...', it obviously implies a pre-scientific view of the cosmos and therefore the psalm cannot comply with the dark green variant of 'Gaian Naturalism'. The last-mentioned subscribes to evolutionary theory and denies that a spiritual world runs parallel to the natural world. This does not, however, prevent the poet to have been a keen observer of the ways and workings of the natural world (for his time and context) and therefore also his appraisal of Yahweh creating 'in wisdom' (bẹhokmāh v. 24). ${ }^{16}$ The creator of this psalm was well informed of the topography of his surroundings, the habitats of different kinds of animals and plants ('species'), their ways (behaviour or 'ethology'), including humans, the seasons and days regulating their movements and sustaining the needs of all living creatures (v. 19-20; see v. $27^{\prime}$ '... give them their food at the proper time [bé'ittô])' and natural disasters like an earthquake (v. 32; Allen 1983:34). This 'natural' knowledge clearly reflected throughout the psalm confirms the cosmos as a liveable home.

Being 'at home' implies more than just physical needs and also includes the feeling(s) of belongingness. Of the emotional well-being of both humans and animals, the poet is well aware. A thirsty animal that has quenched its thirst and satisfied its hunger is obviously a 'happy' animal, verse 28 '... they are satisfied (śby) with good (tôob) things'. The birds that sing cheerily ${ }^{17}$ from the branches of trees along the streams (v. 12) lure Walker-Jones (2001:96) to regard their song as 'praise' to God, anticipating the human praise at the psalm's closing. Humans specifically enjoy being part of earth and savouring her produce: (v. 15) - wine gladdens $(s m h)$ the heart, oil makes the face shine $(s h l)$ with 'glowing health' (Dahood 1970:41) and bread sustains ( $\left.s^{\prime} d\right)$ the heart. The sensuality of enjoying the wholesomeness of the earth is conspicuous. Even God is happily 'at home' in his own creation as he plays (ślq) with Leviathan as with a toy. ${ }^{18}$ The psalm reminds remarkably of the similar divine delight and poet's pleasure in the Joban Divine Speeches (Clines 2013:108). Walker-Jones (2001:90) also interestingly regards the scrambling waters after God has spoken (v. 7-9) as perhaps humorous, compared to Clifford (2003:148) who opts for God as a warrior and the waters as panicking fleeing soldiers. ${ }^{19}$ Both supplicant and divinity rejoice and appreciate the goodness of the created cosmos through the similar

16. Habel (2009:73) indicates that the wise' in the Ancient Near East can be considered as the predecessors of today's scientists, keenly observing phenomena in nature (and society) and describing the 'ways' (drk) of creatures.

17.'The flood-beds produce belts of trees and shrubs along the banks, where the birds nest happily and "give voice" ...' (Eaton 2005:363)

18.'The mysterium tremendum of chaos has been transformed into the mysterium ludibundum' (Brown 2002:161).

19.Even though Walker-Jones (2001:88-90) argues for a 'softer touch' of God towards his creation, with only echoes of the Ancient Near Eastern Chaoskampf present
here (compared to e.g. Ps $74: 14$, 89:10, Is $27: 1$ ), this is still a very powerful God as the verb g'r ('rebuke' v. 7) indicates. Similarly are God's actions later on of merely

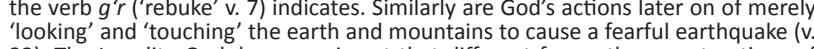
'looking' and 'touching' the earth and mountains to cause a fearful earthquake ( 32). The Israelite God, however, is not that different from other constructions of
the 'divine', for instance wild and dangerous 'nature' also evoking wonder and fear (Taylor 2010:45). Psalm 104's God might be powerful but he is not nature(Taylor 2010:45). Psalm 104's God might be powerful but he is not nature-
unfriendly and the poet portrays the triad God-human-nature as existing in lifesustaining harmony. beginning and ending of the psalm. ${ }^{20}$ The cosmos is truly a pleasant 'home' to all, a 'hospitable household' (Brown 2002:160) and a 'kingdom of life' (Eaton 2005:364).

\section{Interconnectedness}

Psalm 104's cosmological view of a 'living organism' (see Gaia above) ipso facto binds all its constituting elements (biotic and abiotic) together in this whole. The planet as the home to a rich diversity of creatures confirms their interconnectedness and interdependency. Even though different life forms occupy different ecological niches to survive, they all share the same soil, atmosphere, seasons or day-night rhythms, water and basic food stuffs provided by the Earth, with God as the animating force behind it all..$^{21}$ The poet is well aware of differences but skilfully draws no dualisms between nature's constituent parts, as we have become used to in Western thought. Mays (1994:333) says '... creation is unified ontologically with no remnant of cosmic dualism'. Brown (2002:160) confirms this by pointing out the systematic movement of the psalmist from distinction (v. 10ff.) to unity (v. 24, 27-30). Even God who is usually separated ('other-worldly') from the natural world 'permeates' the world in the psalm (Habel 2009:88; WalkerJones 2001:90).

Both Allen (1983:33) and Walker-Jones (2001:93), although they have different demarcations for the subsections of the psalm, as most commentators have, highlight the focus on humans. Allen sees the whole of the psalm as a concentric structure with a strong and pivotal emphasis on verse 14-23, beginning and ending with human labour ('bd). ${ }^{22}$ WalkerJones identifies a chiasm in verse 10-18 with a similar central focus on verse 14-15, 'grass for animals, bread, oil, bread, wine, but plants for people'..$^{23}$ At first glance, this parallel expression seems to elevate human needs above those of others but in fact it does not: 'Humanity is just one among many species and plays a small part in the sweep of the psalm' (Walker-Jones 2001:93). ${ }^{24}$ Humans eat different types of food, but not special food since bread, wine and oil represent Israel's staple food (Allen 1983:27; see also Dt 7:13).

20.Allen (1983:32) extends the inclusio of the psalm to include more than the selfexhortation 'praise the Lord, $\mathrm{O}$ my soul' in verse 1 and 35, namely 'my God' and 'Lord' (v. 1, 33), 'glory' as a synonym for 'majesty and splendour' (v. 1, 31) theophanic language (v. 3, 4, 32), 'forever' repeated (v. 5, 31) and doubly repeated 'wind/breath' (v. 3-4, 29-30).

21.Emphasising 'interconnectedness' from a bodily perspective, Coetzee (2012:115116) recaps the notion of 'absorption' in Psalm 104 as follows: He [poet] experiences his oneness with nature. He is swallowed up in, deeply absorbed by the natural landscape around him. At the same time, the landscape is swallowed into his embodiment, transforming it from within ... The world comes alive emphatically within his body, while he experiences himself as part of the allemphatically within his body, while he experiences himself
inclusive body of the world. He experiences ecstatic moments....

22. Unlike Genesis 3:17 where labour is a punishment, here it is in agreement with God's creational purpose (see also Gn 2:7) (Schaefer 2001:258).

23.The complete chiasm is as follows according to Walker-Jones (2001:93) and can be schematised as a, b, c, d, e, f, $f^{\prime}, e^{\prime}, d^{\prime}, c^{\prime}, b^{\prime}, a^{\prime}$ : wild animals (a), in the mountains (b), birds in the branches (c), Earth satisfied (d), grass for animals (e), bread-oil (f), bread-wine $\left(f^{\prime}\right)$, but plants for people $\left(e^{\prime}\right)$, trees satisfied $\left(d^{\prime}\right)$, birds in trees $\left(c^{\prime}\right)$, in the mountains ( $\left.b^{\prime}\right)$, wild animals $\left(a^{\prime}\right)$. The pairs 'bread-oil' ( $\left.f\right)$, and 'bread-wine' $\left(f^{\prime}\right)$ the mountains $\left(b^{\prime}\right)$, wild animals $\left(a^{\prime}\right)$. The pairs 'bread-oil' $(\mathrm{f})$ and 'bread-wine' $\left(f^{\prime}\right)$ should, however, be re-shuffled (more meaningfully in terms of contents and following the Hebrew word order) to 'bread-wine' and 'oil-bread'. These pairs then form a (micro) chiasm with the outer poles 'bread' and the inner poles the
two 'liquids'.

24.... there is not a hint of anthropocentric claim here' (Mays 1994:334), unlike Psalm 8 and Genesis 1:26-28. 
Unlike the anthropocentric Psalm 8, Psalm 104 inclines to an eco-centrism (Brown 2002:158) where humans 'know their place', and so subscribe to the value of humility emphasised in dark green religion (Taylor 2010:13).

Humans and animals also share time, the seasons marked by the moon and day and night marked by the sun (v. 19-23). The poet, well-informed of 'nature red in tooth and claw' (v. 21; Allen 1983:34) when referring to the lions prowling for prey at night, nevertheless let them live in harmony with their human counterparts who toil for a living during day time. The dark night is not 'bad' or sinister ${ }^{25}$ compared to the light of the day, but simply rhythms to regulate both species' whereabouts '... in a divinely programmed cycle of activity' (Allen 1983:33). And humans' daily toil is certainly not elevated above that of lions, both have intrinsic worth and are allowed to 'be' what they have been created for, to succeed (survive) as lions and humans. The same harmonious being together with another ferocious creature, the sea monster (perhaps a whale? - Allen 1983:27), is exemplified in verse 26. The sharing here comprises a common habitat, the sea where humans with their ships do not naturally belong. The poet has a fine appreciation of peaceful coexistence between species, whether in time and space.

And perhaps, the most conspicuous and important (even ultimate) aspect of interconnectedness is the sharing of the same spark of life breathed in by Yahweh: verse 29-30 '... when you take away their breath, they die and return to dust. When you send your breath (rûh), they are created and you renew the face of the earth'. Habel (2009) recaps the meaning of these verses as follows:

The breath of God - the atmosphere of Earth - is the life-giving spirit permeating all creation. And that breath brings the adamah the fertile ground - to life, greens the landscape and infuses it with God's presence. (p. 89)

Habel also aptly reflects here the ancient Israelite version of Taylor's (2010:14-15) 'Spiritual Animism'. Although not directly stated here, humans share the same rûa $h$ with other life forms (Gn 2:7; see also Gn 6:3); receiving the rûah of Yahweh is the replenishing of humans and animals (Allen 1983:34), losing rûah, means death and humans and animals similarly return to dust, a '... returning home ...' (Gn 3:19; Habel 2009:89). Herewith, the poet also acknowledges the cycle of life and death, where living things' final destination also bind them together as 'kin'. This has also been aptly verbalised by the modern poets exemplified above in their acceptance of death and to be reunited with Earth.

A final example of interconnectedness is the interconnectedness in praise'. Walker-Jones (2001:96) creatively identified the song of the birds (v. 12) as a foreshadowing of the praise of Yahweh towards the end of the psalm. When asking who the ' $\mathrm{I}$ ' is, speaking in the final strophe of the psalm (v. 31-35), he argues that it could be the Earth itself as a 'subject', rejoicing and

25.In Akhenaton's hymn, however, the night is negative: ... the night is a rather siniste time, when the face of the solar god is withdrawn, for the Hebrew poet it is a time time, when the face of the solar god is withdrawn, for the
wisely appointed and used by the Lord ... (Eaton 2005:363) delighting in the Giver and Sustainer of life; or it could be a person speaking collectively on behalf of and as fully part of the whole earth community. Either way, the 'I' represents more than one voice and even invites God himself to celebrate the goodness of creation (see also Gn 1). The psalm's praise, including a greater (metaphysical) reality of interconnectedness, heralds a similar awareness of being part of something larger than oneself, experienced by modern (natural and spiritual) dark green religionists. This final praise also evokes the need for a closer look at the sacredness of nature, why and in which ways can it be considered intrinsically worthy.

\section{Sacredness}

The word sacred is used, usually, in religious circles to indicate a place, object or living thing closely associated with a god or gods and therefore highly valued and respected. A totem (e.g. animal, plant, stone and physical object) is a telling example of having intrinsic worth because of its 'embodiment' of the divine. If the last-mentioned is absent, it is treated as just ordinary 'matter', to be used or misused as human beings deem fit. This was the point raised by Lyn White (1967) in his criticism of (anthropocentric) Western Christianity, namely the emptying of nature of the 'sacred' and therefore its consequential exploiting and plundering. He admires indigenous cultures for not separating god and humanity from nature and creating an unbridgeable dualism. In the same vein, Walker-Jones (2001:87) acknowledges indigenous Fijian culture: 'The Earth has intrinsic worth because gods and ancestors are in vanua [earth] and gods, ancestors, people, flora and fauna are mutually interrelated and interdependent in their support of life'. The same applies to Psalm 104 whose vision is that of monotheistic creation theology, 'valuing' the living world ('works of the Lord') that the scientific term 'nature' does not usually imply (Mays 1994:335). For instance, a modern, natural scientist would usually not describe the impressive cedars of the Lebanon as 'the trees of the Lord ...' (v. 16). God is so closely associated with and present 'in his works' (běma' ás'âyw v. 31, also v.24), wrapping himself in the sunlight, riding on his chariot on wind-driven clouds, making himself heard through thunder and seen in lightning and rain, that he almost becomes indistinguishable from his 'works'. ${ }^{26}$ Most of all '... God is present in Earth as spirit [rûah] providing blessing, fertility and life' (Walker-Jones 2001:91; see v. 29-30). Habel (2009: $87-89,117)$ reiterates that the God of this poet is an 'immanent' God, a 'green' ${ }^{27}$ God that 'permeates' all of nature, and so conferring intrinsic worth on nature.

An apt way of acknowledging the value of nature is through the emotion of awe. Awe can be described as '... perceived vastness, and a need for accommodation, defined as an inability to assimilate an experience into current mental

26.One wonders if the ordinary believer of then (as today), outside of the circles of the 'intelligentsia', would have made these clear-cut distinctions. There was probably a intelligentsia', would have made these clear-cut distinctions. There was probably a merging between the works and the creator itself, especially when the works
personified (animated) - for example, the sun 'knows' when to set (v. 19).

27. Habel (2009:xvii) juxtaposes 'green' with 'grey', to illuminate a biblical text, image of God or human that either acknowledges and respects nature or devalues nature. He also refers to 'grey' texts as inconvenient (embarrassing) texts in the Bible a la Al Gore's book, An Inconvenient Truth. 
structures' (Keltner \& Haidt 2003:297). Westermann (1989:249) describes the experience of the greatness of the Creator and the miracle of his creation depicted in Psalm 104 as difficult to grasp and measure, and it usually leaves the onlooker speechless and overwhelmed (see also Clifford 2003:150; Weiser 1962:667). No wonder the 'divine' (whether as a person, ultimate life-force or ultimate experience) is often referred to as the 'ineffable'. Awe, wonderment and amazement are recognisable throughout the psalm and explicitly at the beginning, middle and end of the psalm: verse 1 'Lord my God, you are very great ... (gādalta $\left.m e e^{\prime} \bar{o} d\right)$ '; verse $24^{28}$ 'How multifarious (rabû) are your works O Lord, in wisdom (běhokmāh) you made them all, the earth is full (mālâ') of your creatures'; verse 31 'May the glory (kébôd) of the Lord endure forever, may Yahweh rejoice in his works (yiśma h běma ăśśāyw)'. To complement awe, Coetzee (2012:119) also emphasises the emotion of joy permeating the whole of the psalm with emphasis on the words śm ('joy' v. 15, 31, 34) and closely related concepts such as brk ('praise' v. 1, 35), šyr and zmr ('sing', 'make music' v. 33).

The non-hierarchical relationship that humans and other living creatures in the psalm have is another indication of their intrinsic worth, where humans usually take centre stage as the most worthy. It has been said above that there is no anthropocentrism in the psalm (Brown 2002:158; Mays 1994:334). Unlike Genesis 1:26-28 (see also Ps 8) where God and humans are separated and elevated from the rest of creation, and humans are given full authorisation to rather brutally rule $(r d h)$ and subdue $(k b s)$ the earth (Habel 2009: 5-6), in Psalm 104 they and other creatures live harmoniously together, each in its own right - cattle eat from the greenery of the earth and so do humans, lions hunt (nightly) for their prey and humans labour (daily) for a living. All share the same 'breath of life' (rûah). Ironically, it is (wicked) humans (v. 35) who incur disharmony (Kraus 1992:128) by undermining the harmonious social and cosmic order (Coetzee 2012:123; Schaefer 2001:258) and hence the prayer that they be removed from the earth. Animals, or the usually blamed forces of chaotic conflict (e.g. 'the deep' and 'seamonster'), are innocent here (Brown 2002:162). Although humans have a stronger presence in the psalm compared to, for instance, the Joban Divine Speeches (Job 38ff.), they are in their 'place' as much as all others. Walker-Jones $(2001: 93,94)$ has insightfully noticed that there is no mutual custodianship in the psalm, where humans usually take up the role of a paternalistic steward ${ }^{29}$ of looking after the earth and its inhabitants and the earth should reciprocate likewise:

... Earth has no need of humans as partners and humanity has no special role as custodian ... Humanity is part of a much larger landscape in which all parts have intrinsic value.

Even the ancient poet had a good grasp of Taylor's (2010:13) emphasis of the smallness of human beings in the universe.

28.This verse functions as a "hinge' to link the preceding section of the psalm with what follows. It is as though the poet is contemplating for a moment on what he has just said, to then continue in similar vein.

29.The founder of the Gaia hypothesis, James Lovelock, is harsh in his criticism of the idea of stewardship and sustainability as typically found in the Abrahamic religions. He regards the idea of human stewardship as arrogant and anthropocentric, the same as appointing goats to be gardeners (Taylor 2010:36)
The naturalist versions of dark green religion ('Naturalistic Animism', 'Gaian Naturalism' acknowledging the life-force instead of a personal 'god') that are doubtful of an objective supernatural world paralleling the natural world, nevertheless express their acknowledgement of nature's intrinsic worth in well-known religious jargon. Awe, wonderment, miracle and so on are common words used, as they experience the same religious-like emotions of believers (Goodenough 2005:1372) when exposed to the beauty of nature. Westermann (1989:250) is therefore quite correct when he says even unbelievers cannot avoid uttering 'O God' in the presence of nature, the same as the believing poet of Psalm 104 (v. 24). A scientific view of nature need not be cold and spiritually bankrupt (see Davidson 1998:342) even though adhering to a natural instead of a supernatural metaphysics. Nature also has the capacity to breach this dualism between belief and (Darwinian) disbelief, one of the beneficiary consequences of dark green religion with its emphasis on nature's intrinsic worth. Where people's beliefs might part, the belief in the last-mentioned binds together.

\section{Conclusion}

The respect and acknowledgment of nature as intrinsically worthy, or the religious equivalent 'sacred', constitutes 'dark green religion'. Dark green religion emphasises a belongingness in nature, an interconnected and interdependent kinship among all and the inspiring belief of the fundamental value of nature. It becomes manifested in a rich diversity of circles (individuals, movements, NGOs, artworks, films, etc.) and it unites adherents that would usually not group together, those with supernaturalist and those with naturalist views. Even the last-mentioned cannot escape the religious-like experience (and jargon) to encapsulate the 'miracle' of nature. This common ground of respect for nature and its implied imperative to act appropriately can only benefit the natural world in this day and age of a severe ecological crisis.

The poet of Psalm 104 has long ago succinctly and intuitively grasped the essence of what is nowadays called dark green religion. As a supernaturalist version of dark green, this poem vividly illustrates the world as a harmonious, living whole. It colourfully depicts Earth as a pleasant home, spontaneously demonstrates the deep-seated kinship among all living creatures and acknowledges nature as sacred through its close association with a nature-friendly ('green') God. The poet's age-old language of awe and reverence standing in the midst of overwhelming nature can also be shared by those who opt for the natural life-force instead of supernaturalism. Therefore, as stated above, even (agnostic) David Attenborough, can express his 'ecstatic' delight in nature, similarly to that of the ancient, believing poet of Psalm 104: 24 'How wonderful your works O God ...'

\section{Acknowledgements Competing interests}

The author declares that he has no financial or personal relationships which may have inappropriately influenced him in writing this article. 


\section{References}

Allen, L.C., 1983, Word biblical commentary 21: Psalms 101-150, Word Books, Waco, TX. Briggs, C.A. \& Briggs, E.G., 1907, The international critical commentary: The book of Psalms, vol. II, T\&T Clark, Edinburgh.

Brown, W.P., 2002, Seeing the Psalms: A theology of metaphor, Westminster John Knox Press, London.

Clifford, R.J., 2003, Abingdon Old Testament commentaries: Psalms 73-150, Abingdon Press, Nashville, TN.

Clines, D.J.A., 2013, 'The worth of animals in the divine speeches of job', in A.H Cadwallader \& P.L. Trudinger (eds.), Hebrew Bible Monographs, 59: Where the wild ox roams: Biblical essays in honour of Norman C Habel, pp. 101-113, Sheffield Phoenix Press, Sheffield.

Coetzee, J.H., 2012, 'Bodily interpretation of Psalm 104: "Yahweh's history" and human ethics', in D.J. Human (ed.), Library of Hebrew Bible/Old Testament studies 572: Psalmody and poetry in Old Testament ethics, pp. 112-127, T \& T Clark, London.

Dahood, M., 1970, Anchor Bible: Psalms III, Doubleday, New York, pp. 101-150.

Darwin, C., 1859, On the origin of species by means of natural selection, or the preservation of favourite races in the struggle for life, 1st edn., John Murray, Albemarle Street, London.

Davidson, R., 1998, The vitality of worship: A commentary on the Book of Psalms, Eerdmans, Grand Rapids, MI.

Eaton, J., 2005, The Psalms: A historical and spiritual commentary with an introduction and new translation, Continuum, London.

Goodenough, U., 2005, 'Religious naturalism', in B. Taylor (ed.), Encyclopedia of religion and nature, Volume 11: $K-Z$, pp. 1371-1372, Continuum, London.

Greaves, R. \& Chryssides, G.D., 2007, The study of religion: An introduction to key ideas and methods, Continuum, London.

Habel, N.C., 2009, An inconvenient text, ATF Press, Hindmarsh.

Hossfeld, F.-L. \& Zenger, E., 2011, Hermeneia: Psalms 3: A commentary on Psalms 101-150, Fortress Press, Minneapolis, MN.

Kaplan, R. \& Kaplan, S., 1989, The experience of nature: A psychological perspective Cambridge University Press, Cambridge.
Keltner, D. \& Haidt, J., 2003, 'Approaching awe, a moral, spiritual and aesthetic emotion', Cognition and Emotion 17(2), 297-314.

Kraus, H.-J., 1992, Theology of the Psalms, transl. K. Crim, Fortress Press, Minneapolis, MN.

Krüger, J.S., 1995, Along edges: Religion in South Africa - Bushmen, Christian, Buddhist, Unisa, Pretoria.

Krüger, J.S., Lubbe, G.J.A. \& Steyn, H.C., 2009, The human search for meaning: A multireligion introduction to the religions of humankind, 2nd edn., Van Schaik, Pretoria.

Mays, J.L., 1994, Interpretation: Psalms, John Knox Press, Louisville, KY.

Palmer Robertson, O., 2015, 'The strategic placement of the "Hallelu-YAH" Psalms within the Psalter', JETS 58(2), 265-268.

Pretorius, H.G., 2016, 'Psalm 104 en die godsdienstradisies van Aten en Baäl', ongepubliseerde PhD-proefskrif, Universiteit van Pretoria.

Schaefer, K., 2001, Berit Olam: Psalms, The Liturgical Press, Collegeville, MN.

Taylor, B., 2005, 'Death and afterlife in Robinson Jeffers and Edward Abbey', in B. Taylor (ed.), Encyclopedia of religion and nature, Volume 1: A - J, p. 455 , Continuum, London.

Taylor, B., 2008, 'From the ground up: Dark green religion and the environmental future', in D.K. Swearer (ed.), Ecology and the environment: Perspectives from the humanities, pp. 89-107, Center for the Study of World Religions, Harvard University Press, Cambridge, MA

Taylor, B., 2010, Dark green religion: Nature spirituality and the planetary future, University of California Press, Berkeley, CA.

Viviers, H., 2016, 'Can the song of songs be described (also) as a form of dark green religion?', Verbum et Ecclesia 37(1), a1581. http://dx.doi.org/10.4102/ve. v37i1.1581

Walker-Jones, A., 2001, 'Psalm 104: A celebration of the Vanua', in N.C. Habel (ed.) The earth Bible 4: The earth story in the Psalms and the Prophets, pp. 84-97, Sheffield Academic Press, Sheffield.

Weiser, A., 1962, Old Testament library: The Psalms: A Commentary, SCM, London. Westermann, C., 1989, The living Psalms, transl. J.R. Porter, T \& T Clark, Edinburgh.

White, L., Jr., 1967, 'The historical roots of our ecologic crisis', Science 155(3767), 1203-1207. http://dx.doi.org/10.1126/science.155.3767.1203 